\title{
Synthesis of Antioxidant Peptides from Melinjo (Gnetum gnemon) Seed Protein Isolated Using Sol-Gel Immobilized Alcalase
}

\author{
Tri Agus Siswoyo ${ }^{\#}$, Nur Fauziah Matra ${ }^{*}$, Anadini Aulia Safiera*, Anang Supriyadi ${ }^{*}$ \\ ${ }^{*}$ Center for Development of Advanced Sciences and Technology (CDAST) and Graduate School of Biotechnology, \\ University of Jember, Jln Kalimantan 37, Jember, 68121, Indonesia \\ E-mail: triagus.faperta@unej.ac.id
}

*Faculty of Pharmacy, University of Jember, Jln Kalimantan 37, Jember, 68121, Indonesia

E-mail: siswoyo.triagus@gmail.com

\begin{abstract}
The synthetic of antioxidant peptides from melinjo (Gnetum gnemon) seed protein isolated using sol-gel immobilized alcalase was studied, a commercial alcalase was physically entrapped in sol-gel matrices system. Characteristics of protein hydrolyzed were evaluated by the degree of hydrolysis obtained (DH) and the peptide profile by FPLC and SDS-PAGE. The antioxidant activity of protein hydrolyzed was determined using ABTS cation, DPPH, and superoxide radical scavenging assays. The DH values increased very quickly during the second hour followed by a slow increase up to 12 hours. Melinjo seed protein isolated was hydrolyzed about $23 \%$ of degree hydrolysis at $50^{\circ} \mathrm{C}$ after 2 hours of incubation. Similar results were also obtained by FPLC and SDS-PAGE, the peptide profile indicated the sol-gel immobilized alcalase was produced of peptides with low molecular weight from melinjo seed protein isolated. Immobilized alcalase preserved the initial activity over 4 cycles of repeated use in a routine reaction. The ABTS assay, the hydrolysate presented a more than 5 times greater activity than non-hydrolyzed melinjo seed protein isolated. It's confirming the potential use of sol-gel immobilized alcalase in synthetic antioxidant peptides from melinjo seed protein isolated.
\end{abstract}

Keywords - melinjo; immobilization; alcalase; antioxidant; peptide; Gnetum gnemon

\section{INTRODUCTION}

Proteases are enzymes used as catalysts for the breakdown proteins by hydrolyzing peptide bond, modification and synthesis peptides [1], [2], [3], [4]. The most common way to generate peptide is enzymatically hydrolyzed proteins and alcalase is one of the enzymes that are often used. This enzyme has the ability with wide specificity to hydrolyze protein or polypeptides with a hydrophobic amino acid such as methionine, tyrosine, tryptophan, phenylalanine, leucine, valine and isoleucine [1]. Some studies have only explained the results of the analysis of enzymatic hydrolysis of protein under working with free soluble. The immobilization of the enzyme on insoluble support reduces the costs associated with the general process and support to stabilize their structure. Selecting the most suitable method of immobilization should be based on several characteristics criteria, such as immobilization costs, greatest immobilized enzyme activity, operational stability and toxicity of immobilization reagents [5]. Methods of immobilizing enzymes have been developed, such as adsorption techniques [6], encapsulating techniques [7], covalent binding [8], [9]. The immobilization of peptidase using adsorption techniques on solid carriers could benefit more than in the free-form, easy to recovery and operation in reuse enzymes in column reactors [10]. The encapsulating techniques using new materials of sol-gels have been found to be compatible for the immobilization of enzymes. Encapsulation of enzymes could be more efficient using solgel material than the other immobilization methods, considering the chemical and thermal stability, does not require covalent modification in its preparation, the entrapment of the enzyme in a larger amount, and the pore size can be controlled [11], [12].

Peptides exhibit a wide range of biological or physiological and functional properties. In the living body, they play the role of mediators and regulators of vital biological functions. It makes an excuse that there is a commercial benefit in the production of enantiopure shortmedium peptides for applications in the nutraceutical and pharmaceutical. Antioxidant peptides as natural antioxidants have been of recent interest due to the strict regulation of synthetic antioxidants. Enzymatic hydrolysis exposes antioxidant amino acids in proteins resulting in peptides with a high antioxidant activity [13]. The antioxidant activity of 
bioactive peptides can be attributed to their metal ion chelation, radical scavenging, and inhibition of lipid peroxidation. Antioxidant peptides can also quench the free radicals and upregulate the expression of proteins and enzymes involved in reducing oxidative stress in the human body. Bioactive peptide activities are based on their molecular size, amino acid composition and sequence and also their usually contain 3-20 amino acid residues [13].

In the past ten years, a great interest has been synthesized of peptides from hydrolysates of various bioresource proteins in terms of their stability and diverse biological activities. Many studies have shown that peptide antioxidants can be produced by enzymatic hydrolysis of various proteins. Some active peptide antioxidant and peptides that can utilize free radicals are identified in various hydrolysates of proteins from plants or animal, including milk, soybean, fish, eggs, seed, and cereal have been used and were reported to have antioxidant activity.

The melinjo tree (Gnetum gnemon L). is cultivated in Southeast Asian islands. Melinjo is native to Indonesia and the seeds are used for sour vegetable soup and also, made into raw chips that later need to be deep fried as emping or crackers. Melinjo crackers are usually served as a complement to Indonesian cuisine. Melinjo seeds contain a high concentration of protein by $9-11 \%$ of the seed and may be considered as a suitable source of functional protein and nutraceutical food supplement [14]. However, there is few study on the use of the melinjo seed protein as a source of active protein for nutraceutical food supplement.

The objective of this study was to examine the sol-gel immobilized alcalase activity to synthesis of antioxidant peptides from the melinjo seed (Gnetum gnemon) protein. In this way, the hydrolyzing activity of sol-gel immobilized alcalase was determined by the degree of hydrolysis, chromatographic and electrophoretic profiles, and antioxidant activity of peptides.

\section{MATERIALS AND METHODS}

\section{A. Material}

Alcalase 2.4 L FG (EC 3.4.21.62) was obtained from Novozyme Nordisk (Denmark), Silane precursors tetramethoxysilane (TMOS, 98\%) and dimethyl dimethoxysilane (DMDMOS, 96\%) were purchased from Fluka (Japan). 2,2'-azinobis (3-ethyl-benzothiazoline-6sulfonic acid) diammonium salt (ABTS) was obtained by Wako (Japan). All other chemicals and solvents were of the highest commercial grade.

\section{B. Methods}

Preparation of immobilized alcalase on sol-gel matrices. The method of immobilization enzymes was adopted on entrapment enzymes on sol-gel matrices as reported by Corici et al., [15]. Alcalase 2.4L solution batch (2.4 AU/gr) was prepared for immobilization. Alcalase solution (3.12 ml), $0.8 \mathrm{ml}$ of $4 \%(\mathrm{w} / \mathrm{v})$ polyethylene glycol 20.000, $0.4 \mathrm{ml}$ of $1 \mathrm{M}$ Natrium Floride, and $0.8 \mathrm{ml}$ of isopropyl alcohol (p.a) in a $10 \mathrm{ml}$ glass vial were mixed using magnetic stirring for $600 \mathrm{rpm}$. Twenty four mmoles of silane precursors dimethyl dimethoxysilane and tetramethoxysilane (1:10f molar ratio) were mixed under continuous stirring. Gelation occurs when the solution mixture was slowly stirred at room temperature $\left(24^{\circ} \mathrm{C}\right)$ until the polymerization completely formed, the gel was kept at $4^{\circ} \mathrm{C}$ for 24 hours and dried at ambient temperature $\left(24^{\circ} \mathrm{C}\right)$ for 48 hours. Finally, the dried gel was pulverized with a mortar into a fine powder and kept at 4$5^{\circ} \mathrm{C}$ in the cold chamber. The protein content was determined in washing solutions [16], and the degree of hydrolysis was analyzed of immobilized enzyme activity using TNBS method.

Melinjo seed protein isolated was extracted from $G$. gnemon seeds and was collected during June-July 2014 from the plants from the collection of the Faculty of Agriculture, University of Jember, South East of Java, Indonesia. After washing and peeling, $25 \mathrm{~g}$ of sample seed was ground in a stainless steel blender (model 38BL19/CB10), and the resulting meal was extracted with $50 \mathrm{~mL}$ of an ice-cold extraction of distilled water for $2-4 \mathrm{~h}$ at $4^{\circ} \mathrm{C}$. The resulting homogenate was run through a filter cloth to remove larger particulate materials and then clarified by centrifugation (10.000 rpm for $15 \mathrm{~min}$ ) in a large-capacity centrifuge. The supernatant was adjusted using $1 \mathrm{M} \mathrm{NaOH}$ at $\mathrm{pH}$. The slurry was then centrifuged at $10.000 \mathrm{rpm}$ for $15 \mathrm{~min}$ to separate soluble and insoluble material. The supernatants were pooled and the $\mathrm{pH}$ was adjusted to 4 . The pellet was separated by centrifugation at $10.000 \mathrm{rpm}$ for $15 \mathrm{~min}$ and washed once with distilled water. The pellet was redissolved in distilled water and $\mathrm{pH}$ was adjusted to 8.0 using $0.1 \mathrm{M}$ $\mathrm{NaOH}$. The protein isolated solution was freeze-dried and then stored at $4^{\circ} \mathrm{C}$ till used for further studies.

Measurement of protein content was done using Bradford's method [16]. The change in the color of Coomassie Brilliant Blue G-250 in Bradford reagent from red to blue was indicated bonding with proteins. The absorbance of the blue color formed colorimetrically at $595 \mathrm{~nm}$ and the protein content was calculated based on a standard curve obtained using bovine serum albumin.

The degree of hydrolysis (DH) was measured using trinitrobenzenesulphonic acid (TNBS) assay [17], and the analytical method was based on Thiansilakul et al., [18]. Total $\alpha$-amino acids were measured in the original of the melinjo seed protein isolated after acid hydrolysis $(6 \mathrm{M} \mathrm{HCl}$ at $100^{\circ} \mathrm{C}$ for $24 \mathrm{~h}$ ) and soluble $\alpha$-amino acid determined in the hydrolytic mixture solution at the beginning and the end of the enzymatic reaction. The TNBS reaction was carried out as follows: $125 \mu \mathrm{l}$ of protein sample was mixed in a test tube (screw cap) with $2.0 \mathrm{ml}$ of $0.2 \mathrm{mM}$ phosphate buffer $\mathrm{pH}$ 8.2 and $1.0 \mathrm{ml}$ of $0.1 \%$ TNBS solution. The mixture was vortexed for $1 \mathrm{~min}$ and placed in a heating block at $50^{\circ} \mathrm{C}$ for $30 \mathrm{~min}$. During incubation, the test tube was covered with aluminium foil. The reaction was terminated by addition of $2.0 \mathrm{ml}$ of $0.1 \mathrm{M}$ Sodium sulfite to the mixture. The mixture was then allowed at room temperature for $15 \mathrm{~min}$. The absorbance of the sample mixture was determined at $420 \mathrm{~nm}$ and the L-leucine solution was used to standardize the quantification of the free $\alpha$-amino group. The degree of hydrolysis was determined as following : $\mathrm{DH}(\%)=[(\mathrm{Lt}-$ Lo)/Lmax-Lo)] x100, where Lt is the amount of $\alpha$-amino acid released at time $t$; Lo is the amount of free amino acid in the original protein isolated; Lmax is total amino acid in the original protein isolated obtained after acid hydrolysis. 
2,2'-azinobis (3-ethyl-benzothiazoline-6-sulfonic acid) diammonium salt (ABTS) radical scavenging activities of protein hydrolyzed were determined as described by [20] [19] with slight modification. The ABTS solution was prepared with the final concentration of $7 \mathrm{mM} \mathrm{ABTS}$ and $2.45 \mathrm{mM}$ potassium persulfate. The mixture was left in the dark at room temperature for $12-16 \mathrm{~h}$ before use. Prior to the assay, the ABTS solution was diluted with $0.2 \mathrm{M}$ sodium phosphate buffered saline ( $\mathrm{pH} 7.4$ ) to an absorbance of 0.70 \pm 0.02 at $734 \mathrm{~nm}$. Then $40 \mu \mathrm{l}$ of the sample containing 2.0 $\mathrm{mg} / \mathrm{ml}$ was added to $4 \mathrm{ml}$ of diluted ABTS solution. The mixture was shaken vigorously for $30 \mathrm{~s}$ and left in the dark for $6 \mathrm{~min}$. An equivalent volume of distilled water instead of the sample was used for the blank. The absorbance of the resultant solution was measured at $734 \mathrm{~nm}$. The ABTS scavenging activity was calculated as [(Ac-As)/Ac] x 100\%, where Ac and As are the absorbance of the control and sample, respectively.

The scavenging effect of on $\alpha, \alpha$-diphenyl- $\beta$ picrylhydrazyl (DPPH) free radical was measured according to the method of Shimada et al. [20] with slight modifications. A volume of $1 \mathrm{ml}$ of each sample was added to $2 \mathrm{ml}$ of $0.1 \mathrm{mM} \mathrm{DPPH}$ in $95 \%$ ethanol. The mixture was shaken and left for $30 \mathrm{~min}$ at room temperature, and the absorbance of the resulting solution was measured at $517 \mathrm{~nm}$. The antioxidant activity was calculated as [(Ac - As $) / A c] \mathrm{x}$ $100 \%$, where Ac and As are the absorbance of the control and sample, respectively.

For the superoxide anion scavenging activity measurement, the autoxidation of a pyrogallol method described by Tang et al., [21] was followed with slight modification. Briefly, $0.1 \mathrm{ml}$ of protein hydrolyzed was mixed with $1.8 \mathrm{ml}$ of $50 \mathrm{mM}$ Tris- $\mathrm{HCl}$ buffer ( $\mathrm{pH} \mathrm{8.2).} \mathrm{The}$ mixture was incubated at $25^{\circ} \mathrm{C}$ for $10 \mathrm{~min}$, and then $0.1 \mathrm{ml}$ of $10 \mathrm{mM}$ pyrogallol (dissolved in $10 \mathrm{mM} \mathrm{HCl}$ ) was added. The absorbance of the solution at $320 \mathrm{~nm}$ was measured up to $4 \mathrm{~min}$. The oxidation rate of pyrogallol for the sample was calculated as the slope of the absorbance line $(\triangle \mathrm{As})$. The autoxidation rate pyrogallol for control was measured with $1.0 \mathrm{ml}$ of double distilled water $(\Delta \mathrm{A} 0)$. The superoxide anion scavenging activity was calculated as $[(\Delta \mathrm{Ao}-\Delta \mathrm{As}) / \Delta$ Ao]x $100 \%$.

The fast protein liquid chromatography (FPLC) of melinjo seed protein isolates and hydrolyzed was performed on a Superdex 200 HR 10/30 column of 7.5 x $300 \mathrm{~mm}$. The column was fitted to an AKTAPURIFIER, FPLC apparatus, equipped with a P-900 pump and UPC-900 model. The eluant was $50 \mathrm{mM}$ phosphate buffer (pH 7.0) $0.15 \mathrm{M} \mathrm{NaCl}$, at a flow rate of $0.5 \mathrm{ml} / \mathrm{min}$. Samples were passed through a $0.45 \mathrm{~mm}$ filter and injected through a 500 ul-loop.

Sodium dodecyl sulfate polyacrylamide gel electrophoresis (SDS-PAGE) was performed in accordance with the method of Laemmli [22]. As the SDS-PAGE gels, use was made of a $15 \%$ and the protein was detected with the use of Commassie Brilliant Blue. To roughly estimate the molecular weight and amount of the protein, molecular weight markers (PageRuler ${ }^{\mathrm{TM}}$ Low Range Unstained Protein Ladder, Thermo scientific; 5 to $100 \mathrm{kDa}$ and a synthetic peptide at $3.4 \mathrm{kDa}$ ) were electrophoresed in such a manner that bands stood for $20 \mathrm{ng}$.
The analyzed spectra were determined using Fourier transform infrared (FTIR). The sol-gel immobilized alcalase and sol-gel un-immobilized alcalase were taken in the wavelength region between 400 and $4,000 / \mathrm{cm}$ at the ambient temperature with a Bruker Alfa FTIR spectrometer (Germany).

The thermal analyses using Differential Scanning Calorimeter (DSC) were performed with Thermoplus EVO, DSC8230, Rigaku, Japan. The calorimeter was calibrated with indium (melting point $=156.7^{\circ} \mathrm{C}$ ) and the reference used was liquid paraffin [23]. The sample (1-3 mg) were weighed in aluminum DSC pans. The pans were sealed and scanned from 50 to $220^{\circ} \mathrm{C}$ at a heating rate of $10^{\circ} \mathrm{C} / \mathrm{min}$ under nitrogen gas. Onset temperature (To) and peak temperature (Tp) of samples; and the enthalpy values $(\Delta \mathrm{H})$ were measured to characterize the thermal properties of samples.

Scanning Electron Microscopy (SEM). SEM photographs were taken with Hitachi TM3000, scanning microscope to examine the morphology, surface structure and inside structure of sol-gel non-immobilized alcalase and sol-gel immobilized alcalase at the required magnification at room temperature. The beads were deposited on brass hold and sputtered with a thin coat of gold under vacuum. Acceleration voltage used was $20 \mathrm{kV}$ with the secondary electron image as a detector.

\section{RESULT AND DISCUSSION}

\section{A. Physicochemical Characteristics of Sol-Gel Immobilized Alcalase}

The protein content of immobilized alcalase on sol-gel matrices in washing solutions disclosed that between 69.1 and $72.8 \%$ of the enzyme has been immobilized and the degree of immobilization had a standard deviation of $1.31 \%$. The FTIR spectra of sol-gel non-immobilized alcalase and sol-gel immobilized alcalase are shown in Fig. 1.

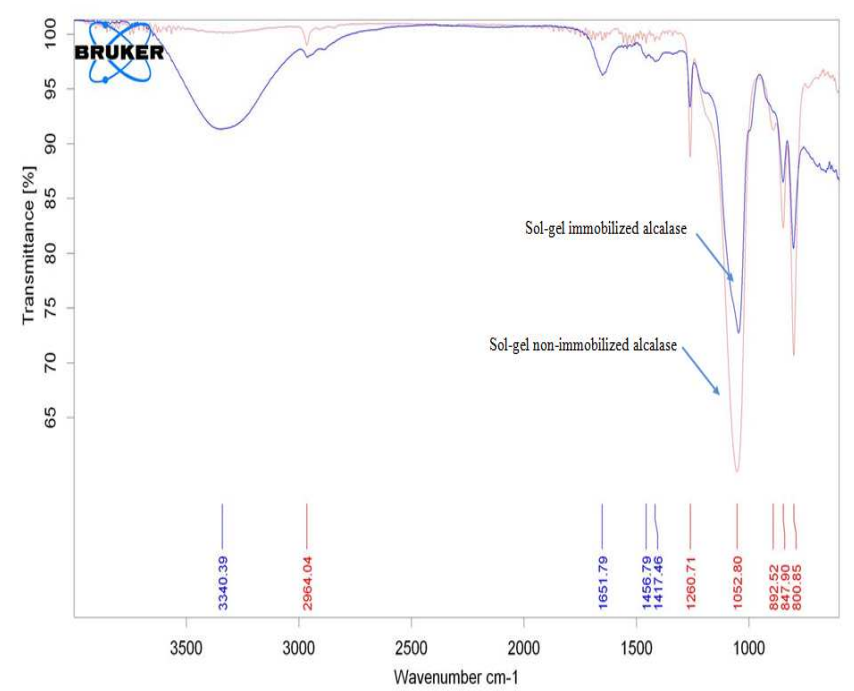

Fig. 1 Infrared spectra of sol-gel non-immobilized alcalase and sol-gel immobilized alcalase 
The sol-gel immobilized alcalase showed a broadband spectrum between 3,000 and $3,700 / \mathrm{cm}$ and which was attributed to $\mathrm{O}-\mathrm{H}$ stretching vibrations. The strong band spectrum of sol-gel immobilized alcalase at $1.260 .71 / \mathrm{cm}$ was indicated to the carbonyl group. Sol-gel immobilized alcalase showed a peak at $1,052.8 / \mathrm{cm}$ and $1,294 / \mathrm{cm}$ due to $\mathrm{C}-\mathrm{N}$ stretching, which confirmed the grafting of the monomer [24].

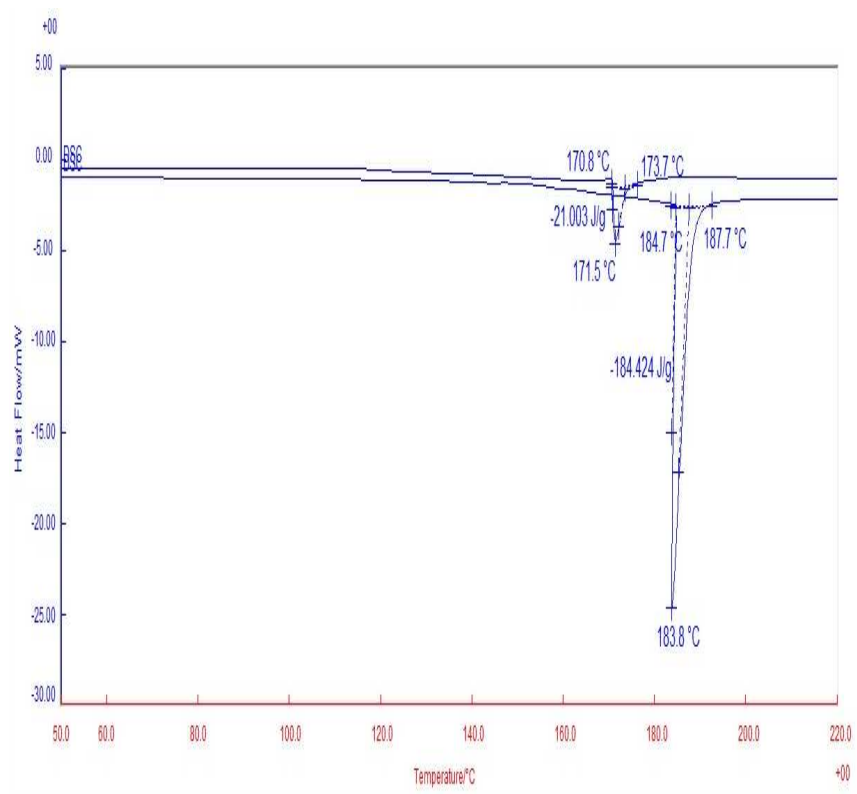

Fig. 2 DSC analysis results of sol-gel non-immobilized alcalase and sol-gel immobilized enzyme

The thermal properties of the sol-gel non-immobilized alcalase and sol-gel immobilized alcalase were performed using DSC analyses, and the representative thermogram results are shown in Fig. 2. Regarding the thermal DSC thermogram in Fig. 2, the temperature of the end points of the Tp shifted to lower temperatures with the grafting of the sol-gel non-immobilized alcalase. The peak temperature value of the sol-gel non-immobilized alcalase was lower than that of sol-gel immobilized alcalase. This is indicated that the grafted chains might act as internal plasticizers. In our data, peak temperature and enthalpy value of the sol-gel non-immobilized alcalase and sol-gel immobilized alcalase were found to be 171 and $184^{\circ} \mathrm{C}$; and 21.0 and $184 \mathrm{~J} / \mathrm{g}$, respectively. The increasing of $\mathrm{Tp}$ and $\Delta \mathrm{H}$ value was seen when sol-gel interacted with enzymes. This increase could be clarified that polymer matrix is more rigid after interacting. Similar observed were reported by Chauhan $e t$ al. [24] and Isiklan et al.[25].

Scanning electron microscopy photographs of the sol-gel non-immobilized alcalase and sol-gel immobilized alcalase taken at 50 and 1,000 times magnifications were shown in Fig. 3. By comparing the surface morphology of internal structure of sol-gel non-immobilized alcalase (Fig. 3A and B) and sol-gel immobilized alcalase (Fig. 3C and D) were shown that the grafted chains changed drastically the morphology of sol-gel formation. As shown in Fig. 3C and $\mathrm{D}$, sol-gel immobilized alcalase are almost spherical in shape and show roughness on the surface.
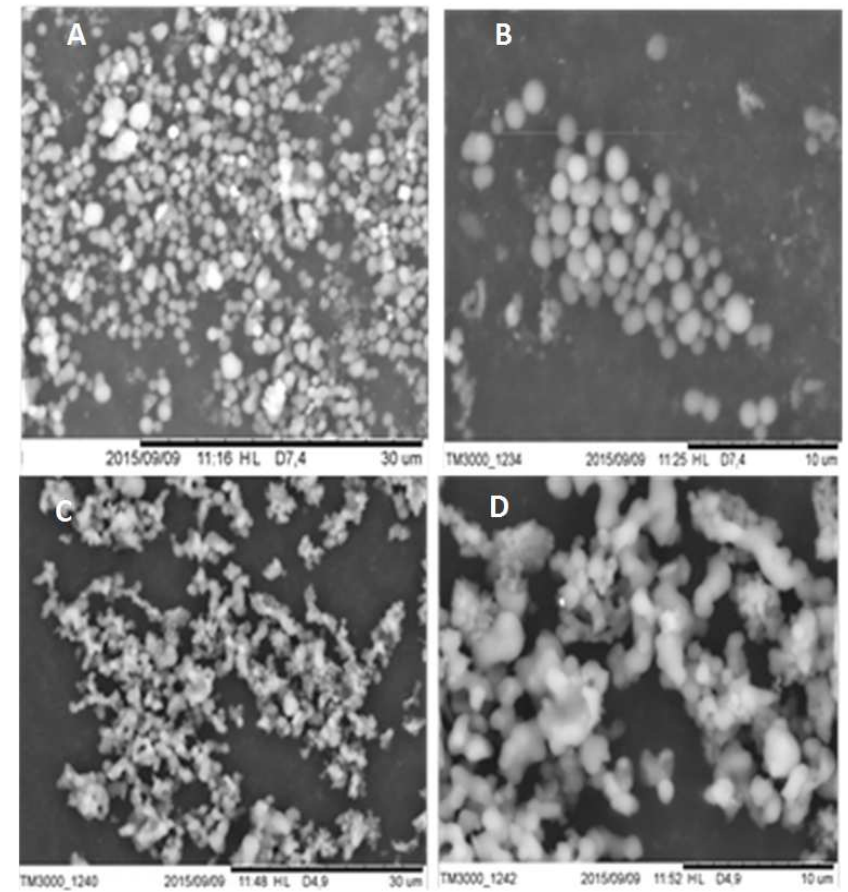

Fig. 3 SEM photographs of cross section of the sol-gel non-immobilized alcalase (A and B) and sol-gel immobilized alcalase (C dan D)

\section{B. Effect of Protein Hydrolyzed Using Sol-Gel Immobilized Alcalase on Antioxidant Activity}

Melinjo seed protein isolated hydrolysis reaction under standard conditions that the enzyme and substrate concentration $(\mathrm{E} / \mathrm{S})$ was $0.8 \%$; the reaction temperature was $50^{\circ} \mathrm{C}$ and $\mathrm{pH}$ was 8.0. Five parallel experiments which hydrolysis time was $0.5,1,2,6$ and $12 \mathrm{~h}$ were carried out, respectively. The results were shown in Fig. 4. It can be seen from Fig. 4 that the degree of hydrolysis (DH) of protein hydrolysate was increased rapidly with the increasing of time of hydrolysis in the from 0.5 to $2 \mathrm{~h}$.

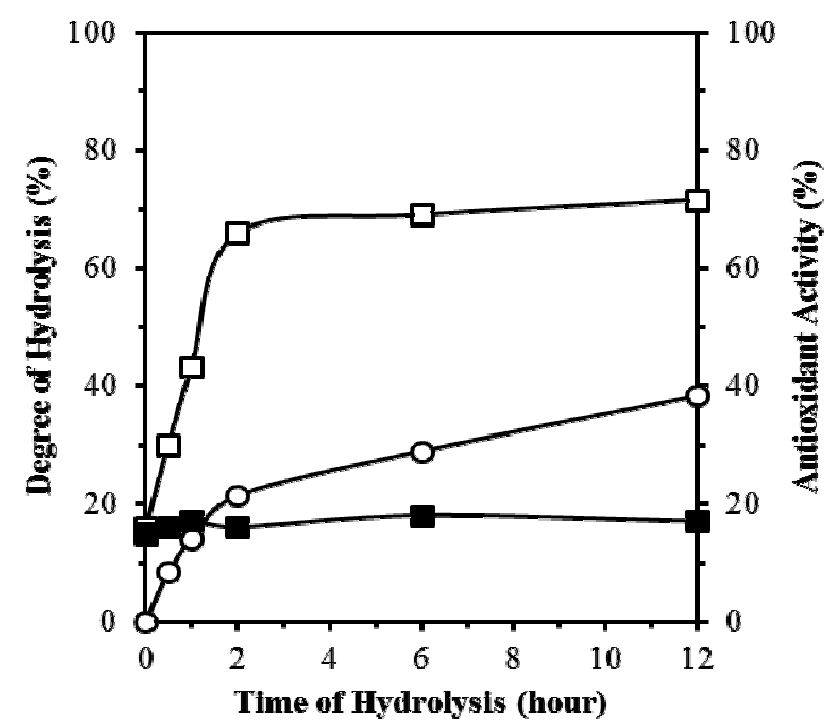

Fig. 4 The degree of hydrolysis and antioxidant activity during hydrolysis of melinjo seed protein isolated with sol-gel immobilized alcalase. The degree of hydrolysis (o), the antioxidant activity of non-hydrolysis protein (घ), and antioxidant activity of hydrolysis ( $\square$ ) 
The hydrolytic activity of the sol-gel immobilized alcalase to protein isolated was stronger in the from 1 to $2 \mathrm{~h}$. This increase can be explained by the fact that the $\mathrm{DH}$ is a measure of the extent of hydrolytic degradation of a protein and is most widely used indicator for proteolytic processes. Furthermore, the hydrolytic activity of sol-gel immobilized alcalase weakened gradually with time when the reaction was longer than $2 \mathrm{~h}$. This reduction of hydrolysis rate might be due to the limited amount of substrate, as the short chain peptides formed might not be further cleaved by sol-gel immobilized alcalase. The reduction of hydrolysis rate might also hypothetically be attributed to the decrease in peptide bonds available for hydrolysis, the decrease in enzyme activity, or product inhibition [26].

The antioxidant activity of melinjo seed protein isolated hydrolysates were determined using ABTS cation scavenging activity method, result presented in Fig. 4. The radical ABTS is reduced with concomitant conversion to a colorless product in the presence of antioxidants with hydrogen-donating or chain breaking properties and the ABTS radical is relatively stable and is readily reduced by antioxidants [27]. Antioxidant activity of melinjo seed protein hydrolysed using sol-gel immobilized alcalase on ABTS radical scavenging activity assay was slightly increased with hydrolysis time up to 2 hours and tended to be static thereafter. The Fig. 4 also shown that the antioxidant activity of melinjo seed protein hydrolysate (68\%) was demonstrated 5 times higher than the nonhydrolyzed $(13.6 \%)$ at 2 hours hydrolysis. The increased antioxidant activity through hydrolysis seems that this shown to process contributed to antioxidant activity by releasing active peptides from melinjo seed protein isolated.

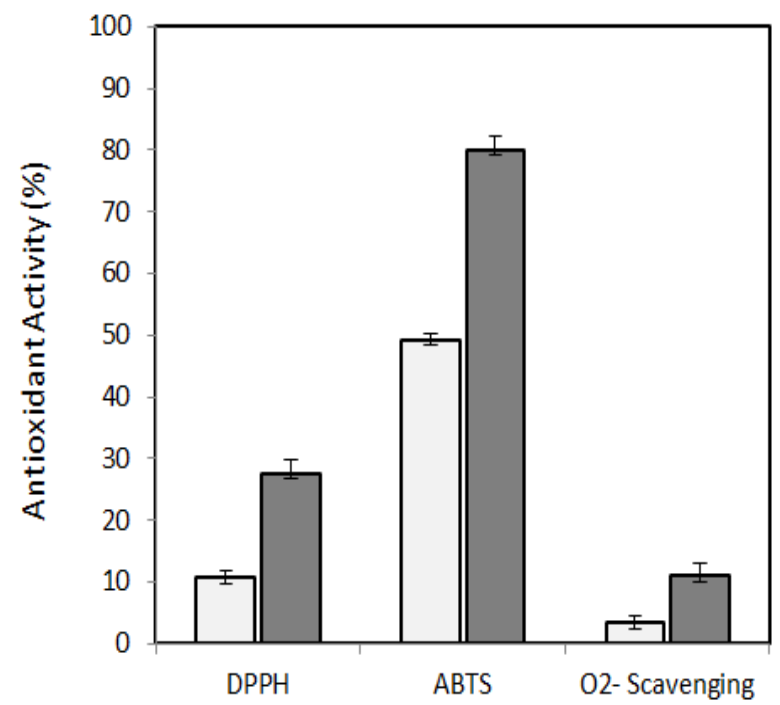

Fig. 5 Comparison of antioxidant capacities of non-hydrolysis ( $\square$ ) and hydrolysis (ם) measured by DPPH, ABTS, and superoxide radical scavenging assays

In this study also compared the antioxidant activity of protein hydrolysate using the DPPH and ABTS scavenging methods. The effects of protein hydrolysate on the scavenging activities are shown in Fig. 5. The scavenging ability of the protein hydrolysed using sol-gel immobilized alcalase on DPPH and ABTS radical was higher than that of non-hydrolysis protein. The antioxidant activity for DPPH radical scavenging were $10.77 \%$ (non-hydrolyzed) and $27.67 \%$ (hydrolyzed) at concentration of $0.25 \mathrm{mg} / \mathrm{ml}$ and ABTS radical scavenging activity were $49.27 \%$ (nonhydrolyzed) and $80.09 \%$ (hydrolyzed) at concentration of $0.04 \mathrm{mg} / \mathrm{ml}$. In addition, the difference between the radical scavenging capacities for DPPH and ABTS could be, in part, due to the difference of the radicals solubility and diffusivity in the reaction medium. Although DPPH scavenging is a widely used method for the assessment of free radical scavenging activity of natural products, it has a notable limitation when used to interpret the role of hydrophilic antioxidants because DPPH can be dissolved only in organic media (especially in alcoholic media), not in aqueous solutions [28], [29]. A further disadvantage is that DPPH serves both as oxidizing substrate and as the reaction indicator molecule; therefore, the assay would easily lead to the problem of spectral interferences [30]. In contrast, ABTS can be solubilized in aqueous as well as organic media; thus, radical scavenging activities of both hydrophilic and lipophilic compounds can be measured [29]. The results suggested that the ABTS method was more sensitive than the DPPH assay for the measurement of the antioxidant activity of water-soluble proteins in an aqueous solution. A similar observation was reported for fermented shrimp bio waste, which exhibited $40 \%$ scavenging activity for DPPH at a concentration of $1.0 \mathrm{mg} / \mathrm{ml}$, compared with a $95 \%$ activity against ABTS even at a concentration of $0.5 \mathrm{mg} / \mathrm{ml}$ [31].

The strongest free radicals of superoxide anion radical in cellular oxidation reactions were produced various kinds of cell-damaging free radicals and oxidizing agents [32]. The activity of superoxide anion radical scavenging was monitored by determining the inhibition of pyrogallol autoxidation that is catalyzed by the superoxide radical. In Fig. 5 also showed, the superoxide anion radical scavenging activity of protein hydrolyzed using immobilized alcalase exhibited the higher activity, about $10.96 \%$ at a concentration of $0.06 \mathrm{mg} / \mathrm{ml}$ compared with non-hydrolyzed $(3.39 \%)$. There were great variations between an intact molecule of protein non-hydrolyzed and hydrolyzed. Intact protein non-hydrolyzed exhibited only a weak superoxide anion scavenging activity than the protein hydrolyzed. Furthermore, inhibitors of protein non- and hydrolyzed using sol-gel immobilized alcalase on pyrogallol autooxidation showed different activities, indicating that hydrolysis of proteins with sol-gel immobilized alcalase will alter the antioxidant potential of the product. It might be due in part to the action of a sol-gel immobilized enzyme that cleaves peptide bonds at specific amino acids and produces a sequence of amino acids with higher antioxidant effects.

\section{Effect of Protein Hydrolyzed Using Sol-Gel Immobilized Alcalase on Synthetic Peptides Profile}

Figs. 6A and 6B show the chromatographic and electrophoretic profiles of the hydrolysates melinjo seed protein isolated during hydrolysis. The clearest change observed in hydrolysates with respect to the melinjo seed protein isolated is the reduction in the molecular weight of proteins. The chromatogram profile of the melinjo seed protein isolated on FPLC using gel filtration shows two major peaks around at 32.80 and $41.89 \mathrm{~min}$. The distribution 
of peptide size in protein hydrolysates using sol-gel immobilized alcalase was shown in Fig. 5A. When melinjo seed protein isolated was hydrolyzed, the peak at 32.80 disappeared after $2 \mathrm{~h}$, and the resulting hydrolysate in FPLC profile was characterized by protein hydrolyzed or peptides that eluted in the range of 162.32 to $174.32 \mathrm{~min}$. This protein or peptides profile was retained until the $2 \mathrm{~h}$ of the sol-gel immobilized alcalase hydrolysis at $50^{\circ} \mathrm{C}$, it's suggesting that no more peptide bonds are hydrolyzed. It is approved by the hydrolysis curves showed that after $2 \mathrm{~h}$, the degree of hydrolysis remained practically unchanged (Fig. 4).

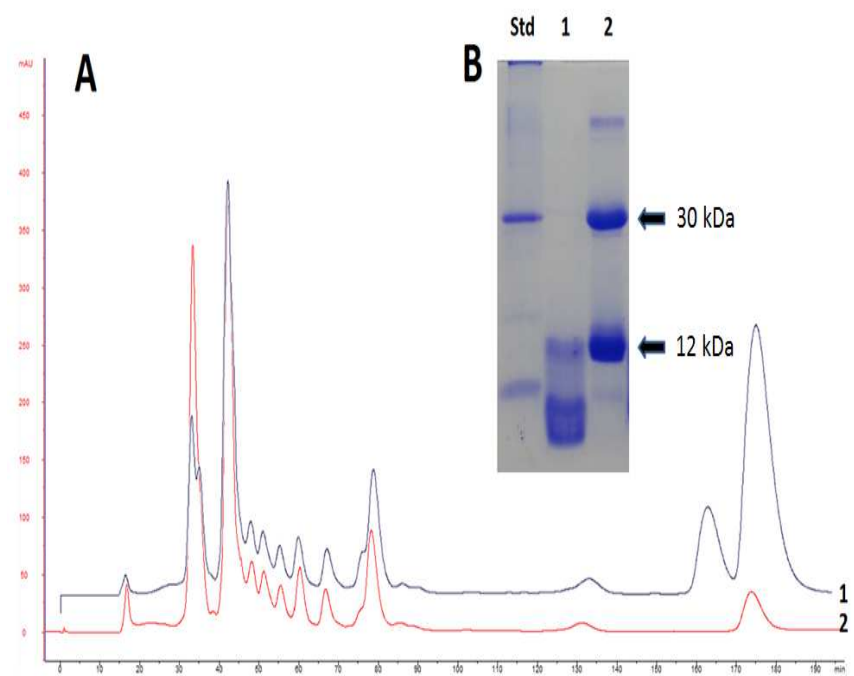

Fig. 6 Effect of hydrolysis of melinjo seed protein isolated using sol-gel immobilized alcalase on the FPLC (A) and SDS-PAGE (B) profile. Melinjo Seed protein hydrolyzed (line 1), and non-hydrolyzed (line 2)

The SDS-PAGE patterns of the sol-gel immobilized alcalase-hydrolyzed isolated melinjo seed protein are shown in Fig. 6B. Non-hydrolyzed melinjo seed protein was composed largely of two polypeptides (line 2). These protein components matched the molecular weight of those reported in the literature [14], that is $30 \mathrm{kDa}$ for a band I and $12 \mathrm{kD}$ for a band II. Hydrolysates generated with sol-gel immobilized alcalase were described by the observation of protein bands II that were resistant to the action of this solgel immobilized alcalase (Fig. 6B, line 1). Moreover, protein band I with a molecular weight around $30 \mathrm{kDa}$, gradually invisible during the incubation with sol-gel immobilized alcalase. This immobilized enzyme was hydrolyzed quickly the peptide bonds of the proteins and protein bands practically invisible after $2 \mathrm{~h}$ of incubation. Instead upon loading a high amount of protein only a band II with about $12 \mathrm{kDa}$ of molecular weight that remained resistant to hydrolysis by sol-gel immobilized alcalase was visible (Fig. 6B).

\section{Reusability of Sol-Gel Immobilized Alcalase}

Reusability is another crucial feature in practical applications of biocatalysts. Leaching and enzyme inactivation is the most prominent drawbacks for large-scale use of sol-gel immobilized enzymes. To investigate reusability, sol-gel immobilized alcalase were reused in hydrolysis system at $50^{\circ} \mathrm{C}$ for $2 \mathrm{~h}$. The sol-gel immobilized alcalase beads were washed with phosphate buffer and were added to a fresh hydrolysis subtract (E/S, 0.8\%). The concentration of peptide was determined in the solution mixture after each hydrolysis. The results of reusability are shown in Fig. 7. In this figure show that the synthesis of the peptide was a sharp decline in the second hydrolysis process around $50 \%$, furthermore in the third and four hydrolysis process did not show a significant change.

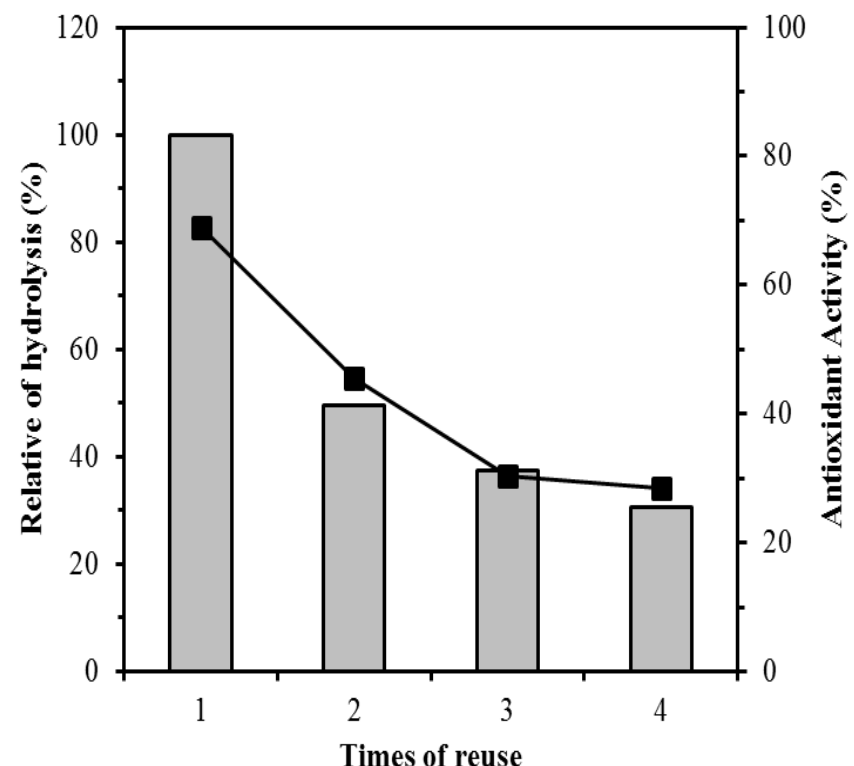

Fig. 7 Reusability of sol-gel immobilized alcalase and antioxidant activity of melinjo seed protein hydrolyzed. Relative to hydrolysis ( $\square)$, and antioxidant activity (

The sol-gel immobilized enzymes may be reused four times with low losing their activity. This loss of proteolytic activity may be caused due to many reasons such as protein denaturation, and or lost enzyme during washing. Similar results have also been reported by Huu et al. [33].

\section{CONCLUSIONS}

The obtained results showed that the hydrolytic activity of the sol-gel immobilized alcalase to melinjo seed protein weakened gradually with time after $2 \mathrm{~h}$. The fast protein liquid chromatography and sodium dodecyl sulfate polyacrylamide gel electrophoresis profile indicated the solgel immobilized alcalase was produced of peptides with low molecular weight from melinjo seed protein isolated. The sol-gel immobilized alcalase retained the initial activity of more than 4 cycles of repeated use in a routine reaction at $50^{\circ} \mathrm{C}$. The ABTS assay, the hydrolysate presented a more than 5 times greater activity than non-hydrolyzed melinjo seed protein isolated. It is confirming the potential use of sol-gel immobilized alcalase in synthesis antioxidant peptides from melinjo seed protein isolated.

\section{ACKNOWLEDGMENT}

We would like to thank the Ministry of Research, Technology and Higher Education, Indonesia for supported this research (Skim STRANAS No. 1871/UN25.3.1/LT/2016) 


\section{REFERENCES}

[1] P. Meinlschmidt, D. Sussmann, U. Schweiggert-Weisz, and P. Eisner "Enzymatic treatment of soy protein isolates: effects on the potential allergenicity, technofunctionality, and sensory properties," Food Sci. Nutri., vol. 4(1), pp 11-23, 2016.

[2] A. Waglay, and S. Karboune, "Enzymatic generation of peptides from potato proteins by selected proteases and characterization of their structural properties," Biotechnol. Prog. vol. 32(2), pp 420-429, 2016.

[3] K. Sangeetha, V. B. Morris, and T. E. Abraham, "Stability and catalytic properties of encapsulated subtilisin in xerogels of alkoxisilanes," Applied Catalysis A: General, vol. 341, no. 1-2, pp. 168-173, 2008.

[4] M.L. Di Gioia, A. Leggio, F. Malagrinò, E. Romio, C. Siciliano, and A. Liguori, "N-Methylated $\alpha$-amino acids and peptides: synthesis and biological activity," Mini Rev. Med. Chem.,vol.16(9), pp.683-690, 2016.

[5] S.F. D’Souza, "Immobilized enzymes in bioprocess," Curr Sci., vol. 77, pp 69-79, 1998.

[6] K. S. Bisht, L. A. Henderson, R. A. Gross, D. L. Kaplan, and G. Swift, "Enzyme-catalyzed ring-opening polymerization of $\omega$ pentadecalactone," Macromolecules, vol. 30, pp. 2705-2710, 1997.

[7] M. T. Reetz, P. Tielmann, W. Wiesenhöfer, W. Könen, and A. Zonta, "Second generation sol-gel encapsulated lipases: robust heterogeneous biocatalysts," Adv. Synth. Catal. vol. 345, pp. 717-728, 2003

[8] S. Ota, S. Myyazaki, H. Matsuoka, K. Morisato, Y. Shintani, and K. Nakanishi, "High-throughput protein digestion by trypsinimmobilized monolithic silica with pipette-tip formula," J. Biochem. Biophys. Methods, vol. 70, pp. 57-62, 2007.

[9] S. Xie, F. Svec, and J. M. J. Frechet, "Design of reactive porous polymer supports for high throughput bioreactors: poly(2-vinyl-4,4dimethylazlactone-co-acrylamide-co-ethylenedimethacrylate) monoliths," Biotechnol. Bioeng., vol. 62, pp. 30-35, 1999.

[10] X. Tian, W. Anming, H. Lifeng, L. Haifeng, C. Zhenming, W. Qiuyan, and Y. Xiaopu, "Recent advance in the support and technology used in enzyme immobilization," Afr J Biotechnol., vol. 8(19), pp. 4724-4733, 2009.

[11] K. Sangeetha, V. B. Morris, and T. E. Abraham, "Stability and catalytic properties of encapsulated subtilisin in xerogels of alkoxisilanes," Applied Catalysis A: General, vol. 341 (1-2), pp. 168$173,2008$.

[12] S. Datta, C.L. Rene, and Y.R.S. Rajaram, "Enzyme immobilization: an overview on techniques and support materials," 3 Biotech., vol.3(1), pp.1-9, 2013.

[13] R.J. Elias, S.S. Kellerby, and E.A. Decker, "Antioxidant Activity of Proteins and Peptides," Critical Reviews in Food Science and Nutrition, vol. 48, pp. 430-441, 2008.

[14] T.A. Siswoyo, M. Eka, K.O. Lee, and K. Hosokawa, "Isolation and characterization of antioxidant protein fractions from melinjo (Gnetum gnemon) seed," J. Agricultural and Food chemistry, vol. 59, pp. 5648-5656, 2011.

[15] L.N. Corici, A.E. Frissen, D.J. van Zoelen, I.F. Eggen, F. Peter, C.M. Davidescu, and C.G. Boeriu, "Solgel immobilization of Alcalase from Bacillus licheniform is for application in the synthesis of Cterminal peptide amides," J. Mol. Catalysis. B, Enzymatic, vol. 73 (14), pp. 90-97, 2011.

[16] M. M. Bradford, "A rapid and sensitive method for the quantitation of microgram quantities of protein utilizing the principle of proteindye binding," Analyt. Biochem. vol. 72, pp. 248-254, 1976.
[17] J. Adler-Nissen, "Determination of the degree of hydrolysis of food protein hydrolysates by trinitrobenzenesulfonic acid," J. Agric. Food Chem., vol. 27(6), pp.1256-1262, 1979.

[18] Y. Thiansilakul, S. Benjakul, and F. Shahidi, "Antioxidative activity of protein hydrolysate from round scad muscle using alcalase and flavourzyme," J. Food Biochem., vol. 31(2), pp. 266-287, 2007

[19] L. You, M. Zhao, J. M. Regenstein, and J. Ren, "Change in the antioxidant activity of loach (Misgurnus anguillicaudatus) protein hyrolysates during a simulated gastrointestinal digestion," Food Chem., vol. 120, pp. 810-816, 2010.

[20] K. Shimada, K. Fujikawa, K. Yahara, T. Nakamura, "Antioxidative properties of xanthan on the antioxidation of soybean oil in cyclodextrin emulsion," J. Agric. Food Chem., vol. 40, pp. 945-948, 1992.

[21] X. Tang, Z. He, Y. Dai, Y. L. Xiong, M. Xie, J. Chen, "Peptide fractionation and free radical scavenging activity of zein hydrolysate," J. Agric. Food Chem., vol. 58, pp. 587-593, 2010

[22] U. K. Laemmli, "Cleavage of structural proteins during the assembly of the head of bacteriophage T4," Nature, vol. 227, pp. 680-685, 1970.

[23] T.A. Siswoyo, and N. Morita, "Thermal Properties of Partially Hydrolyzed Starch- Glycerophosphatidylcholine Complexes with Various Acyl Chains," J. Agric. Food Chem., vol. 51, pp. 3162-3167, 2003.

[24] G.S. Chauhan, B. Singh, S. Kumar, and A. Chinkara, "Synthesis and characterisation of reactive graft copolymers of poly(butyl acrylate) and cellulose," Polymers \& Polymer Composites, vol 13(5), pp. 467477, 2005.

[25] N. Isiklan, M. Inal, and M. Yigitoglu, "Synthesis and characterization of poly (N-vinyl-2-Pyrrolidone) grafted sodium alginate hydrogel beads for the controlled release of indomethacin," J. Applied Polymer Sci., vol. 110, pp. 481-493, 2008.

[26] M.J. Zohuriaan-Mehr, and Pourjavadi, "New polysaccharides copolymers: Synthesis and thermal characteristics," Polym. Adv. Technol., vol. 14, pp. 508-516, 2003.

[27] R. Safari, A. Motamedzadegan, M. Ovissipour, J. M. Regenstein, A. Gildberg, and B. Rasco, "Use of hydrolysates from Yellowfin tuna (Thunnus albacares) heads as a complex nitrogen source for lactic acid bacteria," Food and Bioprocess Technology, vol. 5, pp. 73-79, 2009.

[28] L. J. Zhu, J. Chen, X. Y. Tang, Y. L. Xiong, "Reducing, radical scavenging, and chelation properties of in vitro digest of alcalasetreated zein hydrolysate," J. Agric. Food Chem., vol. 56, pp. 2714 2721, 2008.

[29] M. B. Arnao, "Some methodological problems in the determination of antioxidant activity using chromogen radicals: a practical case," Trends Food Sci. Technol., vol. 11, pp. 419-421, 2000.

[30] K. Dastmalchi, H. J. D. Dorman, P. P. Oinonen, Y. Darwis, I. Laakso, R. Hiltunen, "Chemical composition and in vitro antioxidative activity of a lemon balm (Melissa officinalis L.) extract," LWT Food Sci. Technol.,vol. 41, pp. 391-400, 2008.

[31] N. M. Sachindra, N. Bhaskar, "In vitro antioxidant activity of liquor from fermented shrimp biowaste," Bioresour. Technol., vol. 99, pp. 9013-9016, 2008.

[32] D. Harman, "Role of free radical reactions in aging and disease. J. Geriat. Dermatol," vol. 5, pp. 114-127, 1997.

[33] C. X. Huu, NB Linh, N.T. H. Yen, D.D. Long, "Immobilizing alcalase®enzymes onto magnetic nanoparticles", Comm. in Physics, vol. 24, pp.121-126, 2014. 